Article

\title{
Not Yet the Post-TV Era: Network and MVPD Adaptation to Emergent Distribution Technologies
}

\author{
Mike Van Esler \\ Department of Film and Media Studies, University of Kansas, KS 66044, Lawrence, USA; E-Mail: mwv4zd@ku.edu \\ Submitted: 4 January 2016 | Accepted: 29 February 2016 | Published: 14 July 2016
}

\begin{abstract}
Television as a medium is in transition. From DVRs, to Netflix, to HBO Now, consumers have never before had such control over how they consume televisual content. The rapid changes to the medium have led to rhetoric heralding the impending "post-TV era." Looking at the ways that legacy television companies have adapted to new technologies and cultural practices suggests that rather than traditional television going the way of radio, television as a medium is actually not terribly different, at least not enough to conclude that we have entered a new era. Press releases, discursive practices by the news media, corporate structures and investments, and audience research all point to the rhetoric of post-TV as being overblown. By thinking about contemporary television as being in transition, greater emphasis and attention can be placed on the role that major media conglomerates play in developing, funding, and legitimizing new forms of television distribution, in addition to co-opting disruptive technologies and business models while hindering others.
\end{abstract}

\section{Keywords}

convergence; hulu; Netflix; networks; over-the-top; streaming; television

\section{Issue}

This article is part of the issue "(Not Yet) the End of Television", edited by Milly Buonanno (University of Roma "La Sapienza", Italy).

(C) 2016 by the author; licensee Cogitatio (Lisbon, Portugal). This article is licensed under a Creative Commons Attribution 4.0 International License (CC BY).

\section{Introduction}

In 2012, a new 'television' service was launched that would allow subscribers to access live and recorded over-the-air (OTA) television programming on any device with an Internet connection. Dubbed Aereo, the service challenged traditional definitions and business models for television by rending the 'Where?' of live television consumption out of the living room and severing the 'How?' of it from the television device. Aereo's business model was built on the assumption that viewers wanted to consume content on the go; they wanted to be unshackled from the living room couch (Stelter, 2012a). By capturing OTA signals and storing them on a cloud-based server, Aereo gave its customers what was essentially a DVR that could be accessed by phone, tablet, or computer.

Company executives realized Aereo would upset the broadcast networks and their affiliates and thus tried to avoid litigation by providing each customer with an antenna (and thus a license) which would transmit the feed to the cloud-based server. Doing so meant that Aereo itself was not transmitting the signal, a legality which they believed meant they were in the clear. However, the networks sought an injunction which was initially denied (Stelter, 2012b) before moving to the Supreme Court. There, the streaming service was handed a resounding 6-3 defeat with the Court agreeing with broadcasters that Aereo functioned as a cable system by retransmitting signals (Liptak \& Steel, 2014). Shortly thereafter, Aereo filed for bankruptcy and sold off its remaining assets.

Despite its fate, Aereo is an interesting case study in the rapidly evolving field of television distribution and consumption. While the company attempted to disrupt entrenched models of the industry, it also followed practices of multichannel vídeo programming distributors (MVPDs)-namely, the retransmission of local broadcasts. The only difference was Aereo would not be paying retransmission fees to broadcasters and their affili- 
ates. Effectively, what Aereo did was begin the construction of a cable system (Handel, 2014), complete with a wide selection of OTA channels, as well as licensed cable networks (such as Bloomberg News). The methods of distribution and consumption for Aereo were different than those of traditional cable and satellite providers, but the way in which the programming and content was structured was remarkably similar (indeed, MVPDs were silently rooting for Aereo to succeed because it would allow them to challenge the legality of the compulsory carriage fees from broadcasters). Rather than a revolutionary actor in the contemporary media landscape, Aereo might be considered a service which is caught between traditional and emergent paradigms.

Aereo is not alone in the rapidly evolving television landscape. Numerous platforms like internet protocol television (IPTV) ${ }^{1}$, over-the-top (OTT) content ${ }^{2}$, or subscription video on demand (SVOD) services like Netflix and Hulu have emerged in the past decade as challengers to traditional television broadcasters and MVPDs. The situation has reached such a critical mass that many scholars and journalists have begun touting the 'post-TV era' as a fait accompli or at the very least a moment that is looming in the near future (Leverette, Ott, \& Buckley, 2008; Poniewozik, 2014; Strangelove, 2015; Thompson, 2015). The industry itself seems cognizant of the tumultuous waters it is seeking to traverse, as many media conglomerates endured a weeklong stock market rollercoaster in August of 2015, due in part to uncertainties surrounding television's future (Lang, 2015b). Perhaps most exemplary of the television industry's uncertain future was Disney CEO Bob Iger's suggestion that ESPN-widely considered the most valuable channel in cable and satellite packages-could be sold as an OTT offering in the coming years (Pallotta, 2015). Such a move could be the straw that breaks the camel's back with regards to the bloated bundles that have come to characterize MVPD television packages.

However, we have yet to reach that point. While the media landscape has diversified and expanded at unprecedented rates in the past 20 years, the industry itself has largely remained composed of the same players present in the 1940s during the medium's formative years and the 1980s when MVPDs emerged as important components of the television ecosystem, although market consolidation and conglomeration have introduced a mix of new owners ${ }^{3}$. Not only are

1 IPTV is television that is transmitted over the Internet that does not require an MVPD contract.

2 OTT describes any content which can be accessed independently from MVPDs, although it still usually requires a subscription to the content provider.

${ }^{3}$ As of 2012, 90\% of media outlets (including television) were owned by the same six firms: News Corporation, Comcast, CBS, Disney, Viacom, and Time Warner (Lutz, 2012). There have been no major changes in media consolidation since, although Comcast attempted to purchase Time Warner Cable before the the major corporations that control traditional television production and distribution outfits mostly the same, they also are positioning themselves in strategic locations in the 'post-television' distribution field, as shall be discussed later in the article. If the major media corporations remain at the heart of emerging forms of television production, distribution, and consumption, how useful is it to discuss the contemporary media landscape as 'post-TV'? When home video arose in the late 1970s, why was that socioindustrial development not discussed in the context of 'post-cinema'? The historical moments seem congruent. Thus, if we want to better understand the contemporary historical context of television as both an industry and sociotechnological apparatus, we must avoid assuming that new systems of distribution and consumption inherently signal revolutionary changes.

Instead, as media archaeologist Geert Lovink reminds us, scholars should read their media object of study "into history, not the other way around" (2003, p. 11). Taking such an approach limits teleological pitfalls and allows the scholar to make connections between distinct historical eras, emphasizing the links between different technological apparatuses. While media archaeology generally deals with technologies and not industries, I incorporate elements of it as a methodology when appropriate, particularly when examining the ways new methods of television distribution and consumption relate to traditional ones. Along with media archaeology, I also employ a critical political economy approach as elucidated by David Hesmondhalgh in order to better situate the relationships between industry, technology, and culture. In particular I utilize a critical political economy approach because it examines long-term changes in the relationships between politics, industry, and media in culture (Hesmondhalgh, 2007, p. 33), a component that is essential in understanding the connection between contemporary television and 'traditional' TV. By taking the pertinent aspects of media archaeology and augmenting them with a critical political economy approach, I avoid both engaging in the rhetoric of technological determinism and developing a grand narrative of television distribution history.

Put simply, I argue that rather than use the rhetoric of 'post-TV' to describe the current moment in television history, scholars should consider this a period of transition for the medium, similar to the way that Amanda Lotz (2007) formulates her conception of the 'post-network era.' By thinking about contemporary television as being in transition, greater emphasis and attention can be placed on the role that major media conglomerates play in developing, funding, and legitimizing new forms of television distribution, in addition to co-opting disruptive technologies and business

FCC implied it would reject the deal (Brodkin, 2015). 
models and at the same time hindering others. While being cognizant that consumers have greater agency in this transitory period, I focus most of my attention on industrial firms in this essay because they are the ones who are, for the most part, currently shaping the way content is distributed. Despite new delivery technologies emerging across the globe, I generally focus on an American context because many of the largest media corporations and new methods of distribution are located in the country or have been rapidly adopted there; similar studies could be conducted across different cultures using the same framework, however.

\section{What Is Television?}

When discussing the applicability of the term 'post-TV' to today's media landscape, it is important to first define what is actually meant by television. Television is more than just the material technologies and the stories they broadcast, just as cinema is more than the theater and films. Television includes (but is not limited to): advertising; the cable and satellite infrastructure necessary to transmit signals; systems of audience measurement; national communications regulations; regimes of copyright; audiences; labor negotiations; and transnational flows of culture. The interconnected structure of television is an integral part of understanding it as a concept rather than an object or technology. Thus, I will be referring to the 'television apparatus' throughout, often shortening it just to television, in order to highlight the important relationships between technology, culture, industry, and the state.

The capabilities of modern televisions are indicative of technological convergence and its attendant convergence culture, which Henry Jenkins (2006) suggests opens up the possibilities for a greater participatory culture. New forms of culture require new ways of talking about them, particularly as consumers find new and resistant uses for technology. Amanda Lotz suggests that in an era of increasing technological convergence we should reconceptualize television audiences as niche groups that seek narrowcasting as opposed to broadcasting (2007, p. 5), while at the same time acknowledging that no medium has yet to fill the void for a mass, heterogeneous audience. Lotz's recognition of the lack of replacement for the needs of a mass audience is important because the audience still exists, particularly for marquee events like major world news and high profile sporting events like the Super Bowl or the Olympics, and speaks to the continuing relevance of television as the main technological apparatus that can serve the needs of a wide, diverse audience. ${ }^{4}$

Technological convergence impacts more than just the way audiences are constructed by networks, it also

\footnotetext{
${ }^{4}$ Despite the increasing prevalence of streaming video, live events are still primarily watched on television.
}

influences the forms and content of television productions. Working from a production studies perspective, John Caldwell has argued that television aesthetics in the digital era work in accordance with production practices that prefigured Lotz's post-network era; specifically, Caldwell points to five 'protodigital' elements of production: "ancillary textuality (repurposing, migrating content); conglomerating textuality (convergence texts, TV/dot-com sites); marketing textuality (branding); ritual textuality (pitching, writing by committee); and programming textuality (stunting, sweeps)" (2004, pp. 46-47). These are protodigital strategies because they prefigure the post-TV era, yet see their utility maximized in an era of convergence. For example, ancillary textuality is arguably responsible for the way that (American) television is structured today (Kompare, 2005); while much critical attention is paid to original network programming, syndication makes up most of the programming for a large number of television channels. An era with a proliferation of viewing devices and platforms only increases the necessity of repurposed content and many of the 'disruptive' television services like Hulu relied exclusively on licensed television content to attract customers. The Web also allows the television industry to expand on its practice of conglomerating textuality by providing a space for viewers to interact with augmented narratives and worlds, such as webisodes or alternate reality games (ARGs). ${ }^{5}$ Caldwell's reading of contemporary television production practices as protodigital is useful in refocusing scholars' attention towards residual cultural practices, emphasizing their connection with the past.

Along the same lines, William Uricchio points to the continued relevance of Raymond Williams' (1974) concept of 'flow' for contemporary television. Whereas Williams conceptualized flow as an industrial strategy to suture television programming (including advertising) into a coherent, never-ending cavalcade of content, Uricchio positions his definition of flow in terms of the viewer. Owing to the technological interventions of the VCR and remote control, Uricchio's flow is dependent on the actions and choices of the viewer as opposed to the network programmer (2004, pp. 168172). Uricchio's point is well taken: Not only does he repurpose a bedrock concept of the field, he also historically contextualizes both Williams' and his own concept of flow, noting the myriad technological, regulatory, social, and economic generative mechanisms that define how we interface with television. Uricchio

\footnotetext{
${ }^{5}$ Webisodes are shortform pieces that provide more story or background information for the main televisual text. ARGs use the main text as the source for different types of games that fans play alone or with one another in order to connect more deeply with a text. One of the most famous ARGs was The Lost Experience, a complicated narrative based on $A \mathrm{BC}^{\prime} \mathrm{s}$ Lost and the show's mythology.
} 
also keenly notes that rather than the contemporary televisual moment being one of revolution, we should instead consider it as a transitory period and, in this way, presages Amanda Lotz's (2007) categorization of television's tripartite industrial history.

Writing from a slightly different perspective with regards to the ongoing transformation of television, Michael Strangelove suggests that "a major industrial shift is occurring in the nature of viewing devices, modes of production, and distribution systems" and that the "primary movers of this are not the television and film industries but the consumer electronics industry, the Internet, and the online audience" (2015, pp. 910). Like Uricchio, Strangelove sees the increasing agency of viewers and users as acutely symptomatic of contemporary television. Unlike Uricchio, though, Strangelove attributes this shifting of agency to a new technological order, one whose ideological ground is dictated by consumer electronics manufacturers and telecommunications companies rather than the media industries. This is one point where Strangelove's argument is lacking: many of the traditional media powers are part of multinational conglomerates that include manufacturers and telecommunications giants. Elihu Katz (1996) also sees shifts in television audiences, although his research focuses on the disintegration of the last medium of public space, laying the blame with a proliferation of channels from which audiences can choose. From Katz, we can see further evidence that the decline of 'television' has been heralded for decades. However, the continuing prominence of established media corporations is an essential component of my argument that television is in a transitory period with regards to production, distribution, and consumption practices, yet is not truly removed from the broadcast model that has informed its operations for 70 years.

Despite the "developing analytical orthodoxy" (Tay \& Turner, 2010) of the end of television, the myriad social and industrial practices, technologies, and regulations that constitute the television apparatus suggest that television as we know it remains a vibrant if not evolving medium and cultural object. Audiences may have more consumptive agency and the devices on which they consume content may be changing, but the fact remains that a small number of media corporations determine the layout of the televisual landscape and audiences continue to engage with their media firms (Webster, 2014). In the next section, I unpack the myriad ways in which media and telecommunications companies, with the help of the state via de-regulatory policies, continue to maintain a stronghold on the meaning of television.

\section{A Crowded Field}

The options audiences have for consuming television are rapidly expanding. By the MPAA's count, there were zero legal services for American viewers to watch film and television online in 1997, while that number has since grown to more than 110 . Through these services, consumers watched more than $66.6 \mathrm{~B}$ television episodes with that number estimated to grow to 101.6B by 2019 (Fried, 2015). Such numbers are certainly gaudy and speak to the potential offered by the Internet to expand the way consumers access television content; however, scholars should be careful to take them at their face value because the raw numbers do not speak to the ownership structures and business models behind online video distribution. To get a better sense of what the 66.6B television episodes watched online mean in the larger televisual landscape, I will look first look at the digital services offered by legacy television, including networks and MVPDs. Far from conceding defeat, traditional television players are actively integrating disruptive technologies and models to fortify their position within the market. I will then look at two of the newer, most prominent SVOD services currently in the field-Hulu and Netflix-in order to contrast the narrative of the post-TV era, focusing specifically on their financial structures and market shares, followed by a brief examination of YouTube. Rather than a steady march towards the end of television, closer examination of the contemporary home media field reveals a complex industry made up of traditional and emergent firms competing against and complementing one another, often with both coopting each other's business practices and distribution methods.

\subsection{Networks and MVPDs Go OTT}

Entrenched media powers have been historically hesitant to alter their business models in ways that might jeopardize their bottom line. Film studios were initially reluctant to embrace home video out of fear that it would crater theatrical attendance and take copyright control out of their hands (Greenberg, 2008); more recently, the music industry's reticence to distribute material online led to Apple becoming a dominant figure in the market and dictating licensing terms (Burkart \& McCourt, 2006; Parks, 2012). Despite the Luddism of media industries, they have each successfully integrated emergent business models into their own. Television is no different and after initial reluctance to change from a linear model, networks and MVPDs are slowly offering OTT and IPTV options for viewers.

Network veteran CBS was the first broadcaster to offer a standalone OTT package in 2014. The network announced it would offer viewers access to full seasons of most of its current shows, as well as older programming (although not to their NFL coverage) for $\$ 5.99$ per month with CBS All Access (Poggi, 2014). CBS' decision was remarkable because both networks and MVPDs have historically been against standalone services as it would damage the viability of the cable television bun- 
dle (Kafka, 2015). Speaking at the international television trading expo MIPCOM, Starz executive John Penney goes further: "OTT is a real part of the ecosystem at this point. It's no longer a second or third choice or window for a market; it's considered right along with the cable channels and broadcasters. It's not a scary thing so much as an opportunity-an opportunity to grow the pie and reach more people" (Dawn, 2015). Penney's comments make clear that networks recognize that distributing their content online, in conjunction with either a MVPD or standalone OTT subscription, is now a virtual requirement for survival. This may be construed as evidence that we are now in a post-TV age; however, considering the political economy behind such moves, it seems the dominant interests have adapted aspects of disruptive services to retain their power. Many other networks, both broadcast and cable, have also recognized the necessity to adapt to the new technoeconomic environment, including Showtime, NBC, and AMC (Roettgers, 2015; Spangler, 2015a; Spangler, 2015c).

One network that has embraced alternative forms of distribution with gusto is HBO. Historically an innovator in television, HBO became the first network to transmit its programming via satellite in 1975, leading the way for the MVPD revolution in the 1980s. The company's most relevant contributions to the discussion of a 'post-TV' era are HBO Go and HBO Now, two OTT subscription services. HBO Go launched in 2010 and was available to all subscribers of its linear television counterpart; the service allowed viewers to watch $\mathrm{HBO}$ original programming, licensed films, and sporting events on the Web, mobile and TV-connected devices (such as Roku or AppleTV), and select videogame consoles. HBO Now-launched in April of 2015-is identical in terms of features to HBO Go with one major difference: HBO Now is available as a standalone OTT subscription service.

HBO Now is an important player in the field of disruptive TV services because it demonstrates that networks are willing to adapt to a changing field and embrace streaming while retaining their linear outlets. Critics have suggested that services like HBO Now threaten the business models of linear television, but HBO CEO Richard Plepler disagrees, arguing that telecommunications companies like Comcast and AT\&T should be embracing the service because it allows those companies to upsell other broadband-based products (Wallenstein, 2015). Essentially, Plepler is saying HBO Now is targeted at ISP customers who do not have a cable or satellite subscription yet are interested in specific TV content. It should be noted that HBO Now has not become a revenue generator for the network yet due to initial marketing and technology costs (Lang, 2015a), although executives see it becoming highly profitable in the near future as cable providers realize its potential to bring in consumers who use the
Internet for their media entertainment yet do not subscribe to television.

While in part a reaction to the new distribution models of SVOD and other streaming services, OTT subscription models have precedent with linear television in the form of premium cable networks like HBO, Showtime, and Cinemax. It is true that premium networks require a cable or satellite subscription, yet OTT services also require subscriptions to distribution infrastructure via an ISP or cellular service provider. Thus, while network adoption of OTT is in part reactionary, it should still be viewed as evidence of the staying power of the dominant television paradigm.

Additionally, MVPDs have begun experimenting with new viewing options for consumers. Recognizing the necessity to adapt to the new environment of cordcutters and cord-nevers, ${ }^{6}$ providers like AT\&T and Comcast are offering IPTV services at lower prices than linear TV bundles. Comcast executive Matt Strauss compared new digital distribution models to the music industry, suggesting that Xfinity Stream and others will be as easy as ordering a song online (Spangler, 2015b). Consumer demand has been the impetus behind the new services and is a major part of the emerging TV Everywhere movement which has seen cable providers offer untethered access to programming on mobile devices and MVPDs and networks recognize the urgency of the situation due to the increasing number of households which pay for broadband service but not TV with 10.7 million households opting out in 2014, up 16\% from 9.2 million of 2012 (Steel, 2015a).

Cable providers' willingness to adapt their business models should give scholars pause before perpetuating the narrative of the death of television. With the Telecommunications Act of 1996 deregulating the media landscape, an almost unprecedented number of ISPs, MVPDs, and networks have been merged into telecommunications behemoths. While the effect this has had on television and Internet subscription prices is concerning, it has allowed for greater flexibility among traditional TV firms, most recently evidenced by AT\&T and DirecTV's merger fostering the birth of AT\&T's new telephone, Internet, and TV bundle that allows subscribers access from any device with an Internet connection. The increased diversity of options available to the consumer from legacy TV firms have caused some media analysts to caution against expecting a revolution in television distribution (Koblin, 2015), particularly because the rate of cord-cutting has slowed significantly as the economy improves (Nielsen, 2013). With that said, it is important not to downplay the effect

\footnotetext{
${ }^{6}$ Cord-cutter refers to consumers who cancel their linear television service to watch content online; cord-never refers to younger consumers who have never subscribed to television and have grown up watching content online and on mobile devices.
} 
new entrants into the market like Hulu and Netflix have had, especially in terms of forcing the entrenched powers' hands.

\subsection{Hulu}

Part of the SVOD classification of online services, Hulu was conceived as a web-based TV distribution portal in 2007 ; by 2008, the venture was ready for launch to the public and rolled out the red carpet by purchasing an ad during the Super Bowl in early 2009 featuring 30 Rock star Alec Baldwin promoting the service (Stone, 2009). The choice of Baldwin was not a coincidence as Hulu initially grew via partnership with NBCUniversal and News Corp. (owners of Fox) and was given an unspecified amount of money that would be allotted for advertising the nascent platform on networks owned by the media giants (the Super Bowl aired on NBC that year). Hulu also received $\$ 100$ million in investment capital from Providence Equity Partners in 2007 (James, 2012), a global investment firm which created Newport Television, LLC, a holding company founded for the express purpose of purchasing Clear Channel Communications' 56 television stations. Furthermore, Disney became a partner in 2009, adding content from its family of channels to Hulu (Kramer, 2009); more importantly, though, was the addition of three Disney executives to Hulu's board: Chairman Bob Iger, co-chair Anne Sweeney, and executive vice president Kevin Mayer. Combined with NBCUniversal and News Corp. members, the board of directors at Hulu could be easily mistaken with any traditional television giant's.

Disney's investment in Hulu was critical to the viability of the platform because it extended the exclusive agreements with NBC and News Corp. whereby only Hulu would have access to content licensed by the investment partners (agreements which were about to expire) for another two years. One final aspect of the Disney deal that exemplified the power wielded by the major media conglomerates was that some of Disney's most popular programming would be initially unavailable on Hulu, including Hannah Montana (2006-2011) and High School Musical (2006) (Schechner \& Holmes, 2009). By denying users its most popular programming, Disney was flexing its muscles and letting it be known in no uncertain terms that traditional television powers would dictate, at the very least, the content available to Hulu users.

Beyond major media conglomerate investment and executive board occupation, Hulu also follows the adsupported model of American television. Hulu initially launched as a completely free service that generated revenue by inserting ads throughout a television episode. While much of the world operates under a public television model whereby governments fund programming to varying degrees and by a variety of methods (Hoskins, McFadyen, \& Finn, 1997, pp. 92-95), the
United States has, from its inception, been strongly influenced by neoliberal ideology. Either through program sponsorship or selling time during a broadcast for advertising, American television has consistently been organized around a free market approach. Hulu is no different, as it inserts advertising breaks throughout a user's viewing session (although a user is able to group together the advertisements at the beginning if she wants to watch uninterrupted). Hulu did introduce a subscription option that with limited ads and premium programming options for \$7.99 per month, although the premium tier only has 9 million subscribers as of 2015, nearly 50 million behind rival Netflix (Kastranakes, 2015). The company has not released numbers for how many users opt for the free version of the site, but it seems apparent based on the 700 million hours watched in the first quarter of 2015 that there are far more users choosing the free model (Neuts, 2015). Hulu's subscription numbers are not worthy of ridicule; indeed, they have shown impressive growth recently. However, this does not deny that the service's most active business model is the free, adsupported one, a model that is derived explicitly from the traditional American television model.

Far from being economically and formally disruptive towards the broadcast model of television, Hulu seems to have largely adopted the dominant cultural model for American television. Even subscription pricing speaks to the model pioneered by $\mathrm{HBO}$ and other premium cable networks. Hulu should be considered an important part of the new televisual landscape, though, as many networks are partnering with the company to distribute content online. Comparing Hulu to a much different model will help illustrate how indebted the platform is to traditional television.

\subsection{Netflix}

Starting out as a retail DVD distribution service, Netflix initially emphasized cinema over television series and served as competition for brick-and-mortar video rental stores like Blockbuster and Hollywood Video. However, founder Reed Hastings always intended for Netflix to be an Internet-based service, glibly remarking that there was a reason it was called Netflix and not 'DVD-by-Mail' (Hastings, 2005). In 2007, Netflix launched its streaming service and by 2009 had accumulated 3 million users, an unusually robust level of growth for a nascent service in an emerging field of media distribution (Roth, 2009). Shortly thereafter in 2012, Netflix released its first in-house production, Lilyhammer (2012-2015), and has since continued to ramp up its TV and film production with critically acclaimed content like House of Cards (2013-), Orange is The New Black (2013-), and Beasts of No Nation (2015). Clearly Netflix envisions itself as a major player in the media industry; indeed, Hastings has suggested 
that the traditional linear model of television will be extinct within 10 to 20 years due to consumer demand (Yarow, 2015). However, while such growth and production expansion is important and should not be downplayed as it relates to the health of the traditional television industry, it is a mistake to assume that the ascendance of Netflix is symptomatic of the demise of the television as we know it for two reasons: Netflix's business model, as it is structured in 2015, is not mature enough to judge its viability and viewers' attention is not a zero-sum equation ${ }^{7}$.

The first reason scholars should be skeptical of the claim that Netflix will revolutionize linear television is that its long-term financial viability is far from proven. Netflix operates under a SVOD model whereby consumers have access to Netflix's entire library of content for a flat monthly fee. As of the third quarter of 2015, Netflix had 43 million American subscribers and 69 million global subscribers for their streaming service, dwarfing their competition (Netflix, 2015a). Netflix's subscription numbers are certainly impressive, but they do not speak to the financial solvency of their model, particularly as it relates to their ongoing international expansion into new markets like Spain, Portugal, and Japan (Mai-Duc, 2015; Scott \& Peltier, 2015). Cultivating their brand in new markets is expensive and requires not only capital to develop their infrastructure locally, but also to acquire content that is culturally proximate (Straubhaar, 2003) so as to be able to compete with local video-on-demand services, such as Sky Italia in Italy and Telefonica's Movistar TV in Spain (Anderson \& Rolfe, 2015). In the process of entering new international markets, Netflix's revenue streams have taken a hit, with the company losing $\$ 68$ million internationally in Q3 of 2015 with the company expecting to lose \$117 million in Q4. These international losses are felt throughout the company: in Q4 of 2014 the company posted a global net income of $\$ 83$ million; in Q4 of 2015 , Netflix expects to make a net profit of just $\$ 10$ million (Netflix, 2015a). While the company expects its investment to pay off internationally, local telecommunications infrastructure should caution against rosy outlooks, particularly in southern European markets where broadband penetration rates lag behind the United States.

Netflix also missed its expected domestic subscriber growth mark in Q3 of 2015, adding only 880,000 new customers, falling short of the projected 1,15 million. Poorer-than-expected domestic growth, along with the

\footnotetext{
${ }^{7}$ Netflix has all but disowned its DVD-by-mail service, yet there is a large enough consumer base (roughly 5 million) that the company cannot kill it off completely. That there is still a relatively large subscriber-base for an 'outdated' model suggests that for a variety of technological and cultural reasons, significant portions of viewers remain committed to older methods of media consumption.
}

capital required to expand internationally dampened investors' outlook on the company with the stock tumbling nearly 20 cents per share after the report was announced (Armental \& Ramachandran, 2015). ${ }^{8}$ Investors appear concerned with the new directions that Netflix is taking, but for now it appears that it is too early to say whether or not the company is overheating through in-house productions and international expansion. The uncertain long-term viability of its business model should give scholars caution before accepting Reed Hastings' proclamation that Netflix will be the death of linear television.

The second reason why Netflix is not indicative of the impending 'post-TV' era is simply that viewers are not abandoning television for Netflix. Viewers are able to choose from many options in the contemporary mediascape, of which Netflix is just but one choice. Accordingly, we should think about Netflix's role in the contemporary home media market as similar to that of television in the middle of the $20^{\text {th }}$ century. Initially viewed as a threat to the film industry, television was thought to be a cheap alternative to cinema that afforded the viewer greater choice in content and a more comfortable viewing experience. While television cut into movie-going audiences, it eventually came to be an important revenue source for movie studios as a separate window, as well as a vital advertising outlet (Wasser, 2001, pp. 39-45). We should look at Netflix in the same way-as a competitor for eyeballs, but also an additional revenue outlet for media producers.

Moreover, streaming platforms like Netflix simply are not cannibalizing television at this point in time. As of May 2015, Nielsen found that during primetime, television accounts for $66 \%$ of all home media consumption (Nielsen, 2015b). ${ }^{9}$ The long-term trend may eventually tip the balance of viewing habits in Netflix and company's favor, but at the moment television remains king. Just as cinema adapted its business model and production practices to television, so too will television adapt to streaming competitors.

Netflix is undeniably altering the ways in which people interface with home media, be it through shattering the franchised brick-and-mortar video retail market (Herbert, 2014) or popularizing the consumption habit of binge-watching. However, Netflix itself admits that the entertainment market is big enough for multiple platforms to be successful and that the increased competition will lead to improved services from everyone (Netflix, 2015b). Indeed, as Nielsen found in 2014, the increased number of digital services has spurred a growth in total media consumption, particularly among the prized $18-34$ demographic, which saw a $4 \%$ increase in total hours watched (Nielsen, 2014). Dominant forms of mass media have always had to contend with leisure

\footnotetext{
8 The company's stock has since rebounded.

${ }^{9}$ Radio accounts for the remaining users.
} 
time competitors and, generally, they have survived. Television may eventually be relegated to the fate of radio, but that time has not yet come.

\subsection{YouTube}

YouTube appears to be diametrically opposed to traditional TV. At Google's Q2 2015 Earnings Report, Chief Business Officer and SVP Omid Kordestani (Google, 2015) reported more 18-49 year old Americans accessed YouTube via mobile devices than any cable network; moreover, the average amount of time users spend on YouTube rose to more than 40 minutes, a $50 \%$ year-over-year increase. A survey conducted by DEFY Media (2015) found that $96 \%$ of 13-24 year olds watch YouTube or similar platforms for an average of 11.3 hours per week compared to just $81 \%$ who watch scheduled television. Furthermore, a 2015 Nielsen study (2015a) revealed that between December of 2013 and December of 2014, television viewing by 1849 year olds fell by $10 \%$ while YouTube use increased by $44 \%$. YouTube, it would appear, is cannibalizing television audiences.

Certainly the Google-owned video platform is ascendant in the media ecosystem. The service captures the millennial zeitgeist of snackable content (Grainge, 2011, p. 7) while allowing regular people the chance to create and disseminate media they create without institutional gatekeepers. However, it would be a mistake to argue that YouTube's rise signals traditional television's demise. DEFY Media's survey, while signaling the prominence of YouTube use among 13-24 year olds, also speaks to the staying power of television. When recorded, live, and online TV habits are combined, respondents reported watching 22.2 hours of television per week, almost double that of YouTube and similar platforms (DEFY Media, 2015). This suggests that rather than YouTube muscling out television for viewers' attention, it has carved out a niche with younger audiences, particularly those 24 and under. Additionally, media consumption is not a zero sum gameviewers may be interacting with two screens at once, watching YouTube during commercials for example.

Another item to consider is that media conglomerates have a symbiotic relationship with YouTube, creating much of the site's most popular content and even finding talent for traditional television programming. While it is true that one of the major appeals of YouTube is user-generated content, many of the most popular videos on the site are the products of major media conglomerates, including TV clips, movie trailers, and music videos. The actual percentage of content contributed by the traditional media industries is not quantified, but a 2007 report puts the number between $30 \%$ and $70 \%$ (Holson, 2007). Even if only 30 percent of YouTube content is owned by media corporations, it remains a significant percentage and scholars should estimate that the percentage of content produced by media corporations that users watch is closer to 70 percent. It should also be noted that YouTube introduced an ad-free subscription service named YouTube Red in October of 2015 which could alter the dynamics of user expectations. For example, MTV gave YouTube star Todrick Hall his own show in 2015, viewing it as an opportunity to create content that connects with younger viewers. This particular working relationship benefits all parties involved: Hall is given more creative opportunities, MTV has access to new audiences, and YouTube potentially gains more users.

Rather than look at YouTube as assaulting traditional television, scholars should instead consider the complex ways in which the media and tech industries negotiate balances of power, particularly as media conglomerates absorb aesthetic and economic practices from insurgent platforms.

\section{Conclusions}

Michael Strangelove's suggestion that 'post-TV' orthodoxy may be a strawman is well-taken. It is true that many scholars and critics writing about the state of contemporary television do not explicitly argue that the dominant television paradigm has been usurped by upstarts like Netflix, Hulu, and YouTube; however, what many who write about television distribution and consumption do is rhetorically characterize the contemporary television landscape in terms of a revolution. Indeed, despite his stated temperance, Strangelove posits that "the television industry may be letting the audience slip through its hands" in a migration towards digital options (2015, pp. 8-15); moreover, the book itself is titled Post-TV! Regardless of their stated intentions, Strangelove and others rhetorically position traditional television's death as a fait accompli.

What this article has done is provided a counterbalance to such arguments by illustrating the myriad ways in which the TV industry, in accord with telecommunications companies, have begun adapting to a new technocultural environment where the audience expects to consume content when, where, and how they want. Not only are standalone OTT services becoming de rigeur for networks, MVPDs have begun offering skinny bundles to consumers and TV Everywhere to subscribers. Even the MPAA, normally stridently resistant to any change that might threaten its member studios, has recognized the importance of streaming services to television, arguing against Congressional regulation (Fried, 2015). Rather than declare the contemporary era as that of 'post-TV,' it seems clear that television is in transition and Lotz's (2007) approach of categorizing television in terms of industry practices is more useful for scholars (the post-network era seems most appropriate).

It should be noted that because the rate of change 
in the television industry is so rapid, this article may appear outdated soon after publication. That is a necessary risk when writing about industries in flux, but it does appear that stabilization is in the near-future as cord-cutting rates have slowed and domestic subscriptions to services like Netflix are leveling out. With that said, scholars may well want to examine subscription rates over a 5-10 year period for Netflix to try and discern any trends, particularly with regards to the Great Recession and subsequent economic recovery. Furthermore, in-depth analyses of the economic success or failure of network OTT services, particularly in comparison to rival streaming services, might shed further light on whether or not consumers really are rejecting legacy television in favor of 'post-TV' options.

\section{Conflict of Interests}

The author declares no conflict of interests.

\section{References}

Anderson, A., \& Rolfe, P. (2015, June 8). The challenges Netflix faces during Southern Europe expansion. The Hollywood Reporter. Retrieved from http://www. hollywoodreporter.com

Armental, M., \& Ramachandran, S. (2015, October 14). Netflix subscriber growth disappoints in US. The Wall Street Journal. Retrieved from http://www.wsj.com

Brodkin, J. (2015, May 4). Comcast spent \$336 million on failed attempt to buy Time Warner Cable. Ars Technica. Retrieved from http://www.arstechnica.com

Burkart, P., \& McCourt, T. (2006). Digital music wars: Ownership and control of the celestial jukebox. New York: Rowman \& Littlefield.

Caldwell, J. (2004). Convergence television: Aggregating form and repurposing content in the culture of conglomeration. In L. Spigel \& J. Olsson (Eds.), Television after TV: Essays on a medium in transition (pp. 4174). Durham, NC: Duke University Press.

Dawn, R. (2015, September 30). Mipcom: TV markets scramble to make adjustments as viewing habits transform. Variety. Retrieved from http://www. variety.com

DEFY Media. (2015). Acumen report: Constant content. Retrieved from http://sandbox.break.com/acumen/ Acumen\%20Constant\%20Content_ExecSum\%20 Booklet_Final2.pdf

Fried, N. (2015, October 13). We shouldn't get in the way of streaming video innovation. MPAA. Retrieved from http://www.mpaa.org

Google. (2015). Google (GOOGL) earnings report: Q2 2015 conference call transcript. The Street. Retrieved from http://www.thestreet.com/story/13222530/3/ google-googl-earnings-report-q2-2015-conferencecall-transcript.html

Grainge, P. (2011). Introduction. In P. Grainge (Ed.),
Ephemeral Media: Transitory screen culture from television to YouTube (pp. 1-19). New York: PalgraveMacMillan.

Greenberg, J. (2008). From BetaMax to Blockbuster: Video stores and the invention of movies on video. Cambridge, MA: The MIT Press.

Handel, J. (2014, June 26). Aereo ruling: the winners and losers (analysis). The Hollywood Reporter. Retrieved from http://www.hollywoodreporter.com

Hastings, R. (2005, December 1). How I did it: Reed Hastings, Netflix. Inc. Retrieved from http://www.inc. com

Herbert, D. (2014). Videoland: Movie culture at the American video store. Berkeley: University of California Press.

Hesmondhalgh, D. (2007). The cultural industries (2nd ed.). London: SAGE Publications.

Holson, L. (2007, January 15). Hollywood asks YouTube: Friend or foe? The New York Times. Retrieved from http://www.nytimes.com

Hoskins, C., McFadyen, S., \& Finn, A. (1997). Global television and film: An introduction to the economics of the business. New York: Oxford University Press.

James, M. (2012, April 26). Hulu owners to buy Providence Equity's stake for $\$ 200$ million. Los Angeles Times. Retrieved from http://www.latimes.com

Jenkins, H. (2006). Convergence culture: Where old and new media collide. New York: NYU Press.

Kafka, P. (2015, August 6). Terrible week for TV. Great week for the future of TV. ReCode. Retrieved from http://www.recode.net

Kastranakes, J. (2015, April 29). Hulu hits 9 million subscribers as TV and mobile viewing takes off. The Verge. Retrieved from http://www.theverge.com

Katz, E. (1996). And deliver us from segmentation. Annals of the American Academy of Political and Social Science, 546, pp. 22-33.

Koblin, J. (2015, October 5). Unwrapping the cable TV bundle. The New York Times. Retrieved from http:// www.nytimes.com

Kompare, D. (2005). Rerun nation: How repeats invented American television. New York: Routledge.

Kramer, S. (2009, April 30). It's official: Disney joins News Corp., NBCU in Hulu; deal includes some cable nets. The Washington Post. Retrieved from http://www. washingtonpost.com

Lang, B. (2015a, August 5). HBO now isn't making money yet, execs admit. Variety. Retrieved from http:// www.variety.com

Lang, B. (2015b, August 24). Media stocks face wild ride as markets plunge, recover and plunge again. Variety. Retrieved from http://www.variety.com

Leverette, M., Ott, B., \& Buckley, C. L. (Eds.). (2008). It's not TV: Watching HBO in the post-television era. New York: Routledge.

Liptak, A., \& Steel, E. (2014, June 25). Aereo loses at Supreme Court, in victory for TV broadcasters. The New 
York Times. Retrieved from http://www.nytimes.com Lotz, A. (2007). The television will be revolutionized. New York: NYU Press.

Lovink, G. (2003). My first recession. Rotterdam: NAi Publishers/V2-Organization.

Lutz, A. (2012, June 14). These 6 corporations control $90 \%$ of the media in America. Business Insider. Retrieved from http://www.businessinsider.com

Mai-Duc, C. (2015, February 4). Netflix plans to expand to Japan this Fall in Asian market debut. Los Angeles Times. Retrieved from http://www.latimes.com

Netflix. (2015a). Q3 2015 letter to shareholders. Retrieved from http://files.shareholder.com/downloa ds/NFLX/1226546862×0x854558/9B28F30F-BF2F-4C 5D-AAFF-AA9AA8F4779D/FINAL_Q3_15_Letter_to_S hareholders_With_Tables_.pdf

Netflix. (2015b). Netflix's view: Internet TV is replacing linear TV. Retrieved from http://ir.netflix.com/longterm-view.cfm

Neuts, D. (2015, April 30). Hulu predicts a breakout year in 2015. Subscription Insider. Retrieved from http:// www.subscriptioninsider.com

Nielsen. (2013). Zero-TV doesn't mean zero video. Retrieved from http://www.nielsen.com/us/en/insigh ts/news/2013/zero-tv-doesnt-mean-zero-video.html

Nielsen. (2014). Shifts in viewing: The cross-platform report Q2 2014. Retrieved from http://www.nielsen. com/us/en/insights/reports/2014/shifts-in-viewingthe-cross-platform-report-q2-2014.html

Nielsen. (2015a). The evolution of digital video viewership. Retrieved from http://www.nielsen.com/cont ent/dam/corporate/us/en/reports-downloads/2015reports/nielsen-google-case-study-sept-2015.pdf

Nielsen. (2015b). The total audience report: Q2 2015. Retrieved from http://www.nielsen.com/us/en/insig hts/reports/2015/the-total-audience-report-q2-2015 .html

Pallotta, F. (2015, July 27). Disney's Bob Iger: ESPN could be sold strictly to consumers. CNN. Retrieved from http://www.cnn.com

Parks, K. (2012). Music \& copyright in America: Toward the celestial jukebox. Chicago: American Bar Association.

Poggi, J. (2014, October 16). CBS starts offering its signal over the web as over-the-top gates open. Ad Age. Retrieved from http://www.adage.com

Poniewozik, J. (2014, October 30). The post-television era has begun. Time. Retrieved from http://www. time.com

Roettgers, J. (2015, June 9). AMC Beta-tests streaming service for horror fans. Variety. Retrieved from http://www.variety.com

Roth, D. (2009, September 21). Netflix everywhere: Sorry cable, you're history. Wired. Retrieved from http://archive.wired.com

Schechner, S., \& Holmes, E. (2009, May 1). Disney climbs aboard video site Hulu, teaming up with other net- works online. The Wall Street Journal. Retrieved from http://www.wsj.com

Scott, M., \& Peltier, E. (2015, October 18). Netflix faces challengers in its push to expand globally. The New York Times. Retrieved from http://www.nytimes.com

Spangler, T. (2015a, June 23). Hulu to launch showtime premium package for subscribers. Variety. Retrieved from http://www.variety.com

Spangler, T. (2015b, July 13). Comcast aims at 'CordNevers' with \$15 HBO, ASIC TV internet-streaming bundle. Variety. Retrieved from http://www.varie ty.com.

Spangler, T. (2015c, October 15). NBCU sets 'Seeso' comedy subscription VOD channel launch. Variety. Retrieved from http://www.variety.com

Steel, E. (2015a, July 13). Comcast offers its alternative to cable TV, using the web. The New York Times. Retrieved from http://www.nytimes.com

Stelter, B. (2012a, February 15). A new way to stream broadcast television. The New York Times. Retrieved from http://www.nytimes.com

Stelter, B. (2012b, July 11). Judge says Aereo, a TV streaming service, may continue. The New York Times. Retrieved from http://www.nytimes.com

Stone, B. (2009, February 2). Hulu unveils evil intentions with Super Bowl ad. The New York Times. Retrieved from http://www.nytimes.com

Strangelove, M. (2015). Post-TV: Piracy, cord-cutting, and the future of television. Toronto: University of Toronto Press.

Straubhaar, J. (2003). Choosing national TV: Cultural capital, language, and cultural proximity in Brazil. In M. Elasmar (Ed.), The impact of international television: A paradigm shift (pp. 77-110). Mahwah, NJ: Lawrence Erlbaum Associates.

Tay, J., \& Turner, G. (2010). Not the apocalypse: Television futures in the digital age. International Journal of Digital Television, 1(1), pp. 31-50.

Thompson, D. (2015, July 9). ESPN's plan to dominate the post-tv world. The Atlantic. Retrieved from http://www.theatlantic.com

Uricchio, W. (2004). Television's next generation: Technology/interface culture/flow. In L. Spigel \& J. Olsson (Eds.), Television after TV: Essays on a medium in transition (pp. 163-182). Durham, NC: Duke University Press.

Wallenstein, A. (2015, October 20). HBO CEO Richard Plepler criticizes Comcast, other pay-TV firms for snubbing streaming service. Variety. Retrieved from http://www.variety.com

Wasser, F. (2001). Veni, vidi, video: The Hollywood empire and the VCR. Austin: University of Texas Press.

Webster, J. G. (2014). The marketplace of attention: How audiences take shape in a digital era. Cambridge: The MIT Press.

Williams, R. (1974). Television. London: Fontana.

Yarow, J. (2015, October 15). Netflix CEO explains the 
simple reason his company is succeeding over tradi-

http://www.businessinsider.com

tional TV. Business Insider. Retrieved from

\section{About the Author}

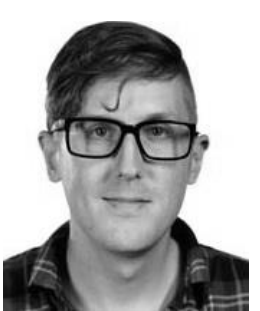

\section{Mike Van Esler}

Mike Van Esler is a PhD candidate in the Department of Film and Media Studies at the University of Kansas. His research interests include digital copyright, virtual communities, media industry regulation, and filesharing practices. Currently he is working on a dissertation entitled The Celestial Box Office: Lineages of Informal Media Sharing Communities which examines the social needs and practices met and fostered by private, unauthorized filesharing communities in the context of historical traditions of informal media sharing economies. 